\title{
An approach to assess the potential of agroecosystems in providing environmental services
}

\author{
Ana Paula Dias Turetta(1), Rafael Tonucci(2), Luciano Mansor de Mattos ${ }^{(3)}$, George Amaro(4), \\ Fabiano de Carvalho Balieiro(1), Rachel Bardy Prado ${ }^{(1)}$, Henrique Antunes de Souza ${ }^{(2)}$ \\ and Aline Pacobahyba de Oliveira(1)
}

\begin{abstract}
(1)Embrapa Solos, Rua Jardim Botânico, no 1024, Jardim Botânico, CEP 22460-000 Rio de Janeiro, RJ, Brazil. E-mail: ana.turetta@embrapa.br,

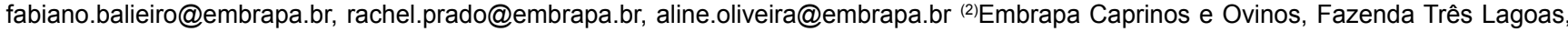
Estrada Sobral/Groaíras, Km 4, CEP 62010-970 Sobral, CE, Brazil. E-mail: rafael.tonucci@embrapa.br, henrique.antunes@embrapa.br (3)Embrapa Cerrados, Rodovia BR-020, Km 18, Planaltina, CEP 73310-970 Brasília, DF, Brazil. E-mail: luciano.mattos@embrapa.br (4)Embrapa Roraima, Rodovia BR 174, Km 8, Distrito Industrial, CEP 69301-970 Boa Vista, RR, Brazil. E-mail: george.amaro@embrapa.br
\end{abstract}

\begin{abstract}
The objective of this work was to present an approach to evaluate soil functions in agroecosystems and their impact on environmental services (ES). An approach with case studies was proposed to assess the relationship between the establishment and management of agroecosystems, in three Brazilian biomes (Atlantic Forest, Cerrado, and Caatinga), and their environmental services provision, considering the specificities of each area. A set of soil parameters that can be used as indicators to monitor changes in the agroecosystem was also proposed. The environmental services types most affected by the establishment and management of the agroecosystems were the supporting and provisioning services, showing the potential of agricultural management in providing multiple services, besides food, fiber, and energy. "No fire use" and "agricultural consortium" were the criteria for the establishment and management of agroecosystems with greater potential to increase environmental services provision, whereas biomass stock in soil and litter was the most appropriate soil parameter to be used as an indicator to monitor the impact of agroecosystems in environmental services provision.
\end{abstract}

Index terms: environmental services indicators, multifunctional agriculture, public policies, soil management, sustainable agriculture.

\section{Uma abordagem para avaliar o potencial de agroecossistemas em prover serviços ambientais}

Resumo - O objetivo deste trabalho foi apresentar uma abordagem para avaliar as funções do solo em agroecossistemas e seus impactos sobre os serviços ambientais (SA). Uma abordagem com estudo de casos foi proposta para analisar a relação entre o estabelecimento e o manejo de agroecossistemas, em três biomas brasileiros (Floresta Atlântica, Cerrado e Caatinga), e a sua correlação com a prestação de serviços ambientais, tendo-se levado em consideração as especificidades de cada área. Também foi proposto um conjunto de parâmetros do solo que possam ser utilizados como indicadores para monitorar as alterações no agroecossistema. Observou-se que os tipos de serviços ambientais mais afetados pela implantação e pela gestão dos agroecossistemas são os de suporte e provisão, o que mostra o potencial que o manejo agrícola tem de fornecer múltiplos serviços, além de alimentos, fibras e energia. "Sem uso de fogo" e "consórcios agrícolas" foram os critérios usados na implantação e a gestão de agroecossistemas com maior potencial em aumentar a prestação de serviços ambientais, enquanto o estoque de biomassa no solo e na serapilheira foi o parâmetro do solo mais adequado para uso como indicador no monitoramento do impacto do agroecossistema na prestação de serviços ambientais.

Termos para indexação: indicadores de serviços ambientais, agricultura multifuncional, políticas públicas, manejo do solo, agricultura sustentável.

\section{Introduction}

The agroecosystem concept can be used to analyze food systems as wholes, including their complex sets and outputs, as well as the interconections between their ocmponents, resulting in benefits for the whole system (Gliessman, 2006).
Agroecosystems may benefit soils, by improving soil functions (Andrews \& Carrol, 2001; Fultz et al., 2013; Salomé et al., 2016) and by improving an environment for plant growth (Altieri, 1999; Baiduforson et al., 2012), water supply regulation (Willaarts et al., 2012; Barral et al., 2015), nutrient cycling (Wang et al., 2014; Singh, et al., 2016), atmospheric 
modification, construction foundation, and a habitat for many organisms (Doran \& Parkin, 1994; Jalloh et al., 2012; Lescourret et al., 2015), besides providing environmental services (ES) (Dale \& Polasky, 2007; Dominati et al., 2010). All these examples highlight the benefits of agroecosystems to society, in addition to food production.

A term that has been widely used to indicate the many functions and benefits provided by agroecosystems is "multifunctional agriculture" (MFA). It recognizes the inescapable interconnectedness between agriculture's different roles and functions, that is, that agriculture is a multi-output activity, producing not only commodities, but also non-commodity outputs, such as environmental services, landscape amenities, and cultural heritages (Unep, 2016). The MFA concept entered definitely in the sustainable development debate after being addressed in the Agenda 21 documents of the 1992 Earth Summit in Rio de Janeiro, Brazil (Rossing et al., 2007). Since then, it has obtained an increasingly important role in scientific and policy debates on the future of agricultural and rural development (Renting et al., 2009).

The multifunctional capacity of agroecosystems is directly linked to the provision of ES, defined as the benefits people obtain from ecosystems. The Food and Agriculture Organization of the United Nations (FAO, 2011) stresses that healthy ecosystems provide a variety of vital goods and services that contribute directly or indirectly to human well-being, in economic, social and environmental spheres. These services include: provisioning services, such as food, wood, fiber, and fuel production, as well as fresh water; regulating services, like flood, disease, and water quality control, besides carbon storage, waste treatment (nutrients and pesticides), and climate regulation through greenhouse gas emissions; cultural services, comprising spiritual, recreational, and cultural benefits, associated to scenic beauty, education, recreation and tourism; and supporting services, such as nutrient cycling and primary production, which maintain the conditions for life on Earth (Millennium Ecosystem Assessment, 2005; Power, 2010).

Although agroecosystems may have low ES values per unit area, when compared with other ecosystems, they offer the best chance of increasing global ES - given the proportion of land devoted to agriculture worldwide - by defining appropriate goals for agricultural and land use management regimes that favor the provision of these services (Porter et al., 2009). In other words, it is possible and essential to improve ES provision from agriculture through agricultural management practices.

However, to reliably define the connections between agricultural practices and ES provision is still a challenge, since many factors, specific to each case, are involved. For this reason, it is necessary to define key factors to be considered in such approach. Dominati et al. (2010) presented a conceptual framework for classifying, quantifying, and modeling soil natural capital and ecosystem services. Lescourret et al. (2015) proposed a social-ecological conceptual framework to address the issue of multiservice management in agroecosystems. This approach tried to cover a gap observed by Binder et al. (2013), who found that social and ecological components were rarely treated with equal depth and that there was not always reciprocity between both systems. Moreover, once the link between agricultural practices and ES provision is well established, it is possible to use this information to support decision making, even those related to the payment of ecosystem services.

Since the 1990s, ES has been used in Brazil to draw the attention of public opinion and decision makers to the values of ecosystems, particularly in relation to water supply in the Atlantic Forest, to the impacts of deforestation and forest degradation in the Amazon, and to the expansion and financing of protected areas in different biomes (Ring, 2008; Börner et al., 2010; Eloy et al., 2013).

A fundamental point concerning agroecosystems and their potential to provide ES is defining indicators to evaluate the impact of soil management on ES provision. Many efforts have been made in the search for indicators to assess soil quality (Niemeijer \& Groot, 2008; Lal, 2010; Schipanski et al., 2014). Dale \& Polasky (2007) stated that the challenge for selecting ecological indicators to link agroecosystems and ES provision is to identify the main features that represent the compositional, structural, and functional components of the system, which are important in the provision of ES.

The The objective of this work was to present an approach to evaluate soil functions in agroecosystems and their impact on environmental services (ES). 


\section{Materials and Methods}

Three regions were considered for the case studies: the amended waters region, located at Distrito Federal, the country's federal district, and characterized by the Cerrado (Brazilian savanna) biome; the Inhamuns/ Crateús region, in the state of Ceará, covered by the Caatinga biome; and the Pito Aceso watershed, at the mountainous region of the state of Rio de Janeiro, characterized by the Atlantic forest biome (Figure 1). All regions are typical agricultural areas, representative of family farming in each biome.

The amended waters region and the Inhamuns/ Crateús region are part of the "Programa Territórios da Cidadania", the citizenship territories program for Brazil, which was created by the federal government in 2008 and defines 135 regional development actions and social rights that should be guaranteed in areas with the lowest human development index (HDI) within the country (Brasil, 2016b).

The "Território da Cidadania das Águas Emendadas" (TCAE), i.e., the amended waters citizenship territory, is formed by Distrito Federal, more specifically the city of Brasília, and by ten municipalities in two adjacent states, Goiás and Minas Gerais, as shown in Figure 1. TCAE has an average HDI of 0.83 , covers an area of $37,721.70 \mathrm{~km}^{2}$, and its total population is around $2,898,988$ inhabitants, of which 146,190 , i.e., $5.04 \%$ of the total, live in rural areas (Brasil, 2016b). TCAE is located in the Cerrado biome, the second largest in South America, occupying an area of 2,036,448 $\mathrm{km}^{2}$, representing about $22 \%$ of the national territory. Considered one of the world's biodiversity hotspots, the Cerrado presents extreme abundance of endemic species. Besides its relevance in biodiversity, it stands out in social and economic aspects. Many people

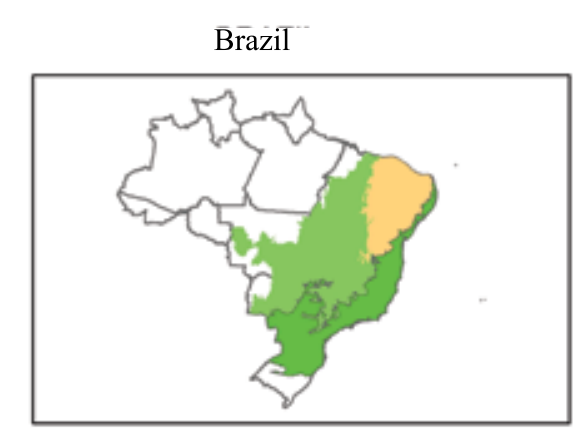

Study areas

States limit

Biomes

Caatinga - Inhamus/ Crateus Region

Savannah - Amended Waters Region

Atlantic Forest - Mountain Region of Rio de Janeiro State

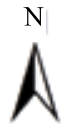

Geographic projection Datum SAD69

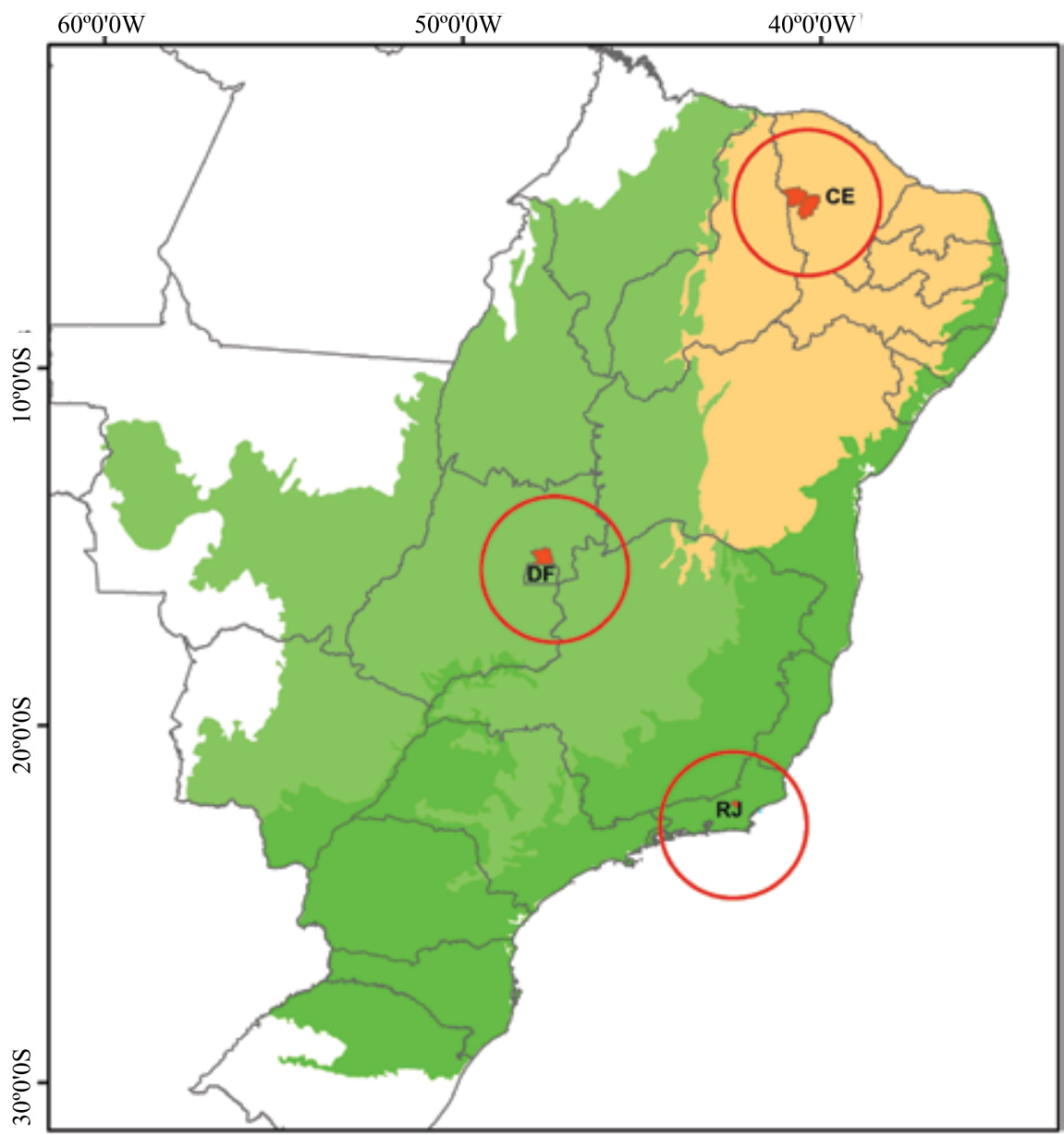

Figure 1. Location of the case study areas in Brazil, that is, of the Caatinga, Cerrado (Brazilian savanna), and Atlantic Forest biomes. DF, Distrito Federal; CE, state of Ceará; and RJ, state of Rio de Janeiro. 
survive from the Cerrado's natural resources, including indigenous people, riverine groups, and "quilombo" communities. The Cerrado is also the largest Brazilian grain-producing region, showing the importance of this biome for Brazilian agribusiness (Brasil, 2016a). The average annual temperature in the Cerrado is $24^{\circ} \mathrm{C}$. In spring and summer, the temperature can reach $40^{\circ} \mathrm{C}$, and, in winter (June, July, and August), it is around $12^{\circ} \mathrm{C}$ and may reach $0^{\circ} \mathrm{C}$. In these colder days, the presence of frost can occur, especially in the southern area of the Cerrado. The average annual rainfall is around 1,300-1,700 $\mathrm{mm}$. Much of the rain is concentrated from October to March, that is, in the spring and summer seasons. Between May and September, is the dry season, a period when the rains are rare and natural fires may occur (Brasil, 2016a).

The "Território da Cidadania Inhamuns/Crateús" (TCIC), that is, the Inhamuns/Crateús territory in the state of Ceará, is located in the semiarid region, covering an area of $30,795.60 \mathrm{~km}^{2}$ and consisting of 20 municipalities. The total population of this territory is around 524,000 inhabitants, of which approximately 235,000 live in rural areas, corresponding to $44.94 \%$ of the total. It has 45,145 farmers, 3,649 resettled families, 12 "quilombo" communities, and 1 indigenous land (Brasil, 2016b). TCIC is part of the Caatinga biome, which occupies an area of about $844,453 \mathrm{~km}^{2}$, equivalent to $11 \%$ of the Brazilian territory. The Caatinga has great potential for ES provision - its biodiversity sustains many economic activities for agricultural and industrial purposes, particularly in the pharmaceutical, cosmetic, chemical, and food branches (Brasil, 2016a). Since the climate of this region is semiarid, the temperature during the year varies little - the annual average is between $25^{\circ} \mathrm{C}$ and $28^{\circ} \mathrm{C}$. Moreover, rain occurs in small quantities, and the annual rainfall is around $700 \mathrm{~mm}$, concentrated between January and May (Brasil, 2016a).

The Pito Aceso watershed (PAW), located at the mountainous region of the state of Rio de Janeiro, is not included in the Brazilian citizenship territories program, but is an important area in the state. It has 16 municipalities, with 873,837 inhabitants, representing $5.3 \%$ of the total state population. Between 1995 and 2008 , the employment in agriculture in this region increased more than $30 \%$, showing its importance regarding social and economic aspects (Seminário..., 2007). This region is covered by the Atlantic Forest biome, a set of forest formations and associated ecosystems, such as salt marshes, mangroves, and high fields, which originally stretched for about $1,300,000 \mathrm{~km}^{2}$ in 17 states of Brazil. Today, the remnants of native vegetation are reduced to about $22 \%$ of the original cover and are in different stages of regeneration. Although the Atlantic Forest is small and fragmented, it is estimated that it comprises about 20,000 plant species, which represent about 35\% of the existing species in Brazil, including several endemic and endangered ones. Besides being one of the richest regions of the world in biodiversity, it is the most populated biome in the country - approximately 120 million people live there - and also the richest - it makes up about $70 \%$ of Brazil's gross domestic product (GDP) (Brasil, 2016a). Because the Atlantic Forest is in the transition zone from the tropical to subtropical climate, it is characterized by a hot and humid season from November to March (summer) and by a cold and dry one from May to August (winter). The proximity to the ocean and to the mountains contributes to a predominantly hot and humid local climate, with high temperature and humidity. Temperatures and rainfall vary with altitude, decreasing $0.6^{\circ} \mathrm{C}$ and increasing about $200 \mathrm{~mm}$ per $100 \mathrm{~m}$ of altitude, respectively. The average annual temperature on the coast is $22^{\circ} \mathrm{C}$, decreasing about $11^{\circ} \mathrm{C}$ at $2,000 \mathrm{~m}$. The annual rainfall average at sea level is $1,600 \mathrm{~mm}$.

Considering the specificities of each biome, criteria were established to improve the ES provided by each agroecosystem (Table 1). For each criteria and ES type, graduations were proposed according to biome

Table 1. Criteria for the establishment and management of agroecosystems in the Atlantic Forest, Caatinga, and Cerrado biomes.

\begin{tabular}{lccc}
\hline Criteria & Cerrado & $\begin{array}{c}\text { Caatinga } \\
\text { Notlantic } \\
\text { Forest }\end{array}$ \\
\hline Rational use of agrochemicals ${ }^{(1)}$ & Yes & Yes & Yes \\
No use of agrochemicals ${ }^{(1)}$ & No & No & Yes \\
Permanent litter on soil surface & Yes & Yes & No \\
Agricultural consortium & No & No & Yes \\
Crop rotation & Yes & Yes & Yes \\
Native trees & Yes & Yes & Yes \\
Use of irrigation & No & Yes & No \\
Inclusion of animal component & Yes & No & Yes \\
Strategy of water use in the rural property & Yes & Yes & Yes \\
\hline
\end{tabular}

${ }^{(1)}$ Chemical fertilizers and pesticides. 
characteristics and requirements, as well as a set of soil parameters that can be used as indicators to monitor ES improvement. This information was organized based on the knowledge of biome characteristics associated with social, economic, environmental, and agricultural aspects.

In each area - TCAE, TCIC, and PAW -, the criteria for the establishment and management of agroecosystems were validated with representatives of agricultural entities, producers, and the research team. Afterwards, the groups systematized the information and defined the priorities for each biome concerning agroecosystems, ES provision, and indicators to monitor the proposed changes. Information about public policies was also considered, since these are crucial to enable changes in the agriculture and environment sectors. The improvement of ES provision from agriculture represents a real chance for Brazil to meet the international agreements about climate change.

\section{Results and Discussion}

The criteria for the establishment and management of the agroecosystems in each study area are presented in Table 2. It was observed that the ES that were most affected were the supporting and provisioning types, which showed multifunctionality in agriculture: supporting services, for example, are related to nutrient cycling and primary production, whereas provisioning services include food, wood, fiber, and fuel production, as well as fresh water. Yahdjian et al. (2015) point out that supporting services, particularly biodiversity and nutrient cycling, are essential to other ecosystem services, since they affect the supply of provisioning, regulating, and cultural services. Furthermore, Lal (2010) highlights that the increase in supporting services improves soil quality and crop yield, and also reduces soil erodibility and carbon dioxide $\left(\mathrm{CO}_{2}\right)$ emissions into the atmosphere. Schipanski et al. (2014) found that agricultural management may provide supporting services through biological nitrogen fixation by legumes and through nitrogen mineralization from cover crop residues. These factors reflect the potential to support crop production through internal nutrient cycling, reducing the use of synthetic fertilizers and their associated fossil fuel emissions. In addition, excessive nitrogen inputs can increase nitrate $\left(\mathrm{NO}_{3}\right)$ pollution in streams and groundwater, and nitrous oxide $\left(\mathrm{N}_{2} \mathrm{O}\right)$ emissions into the atmosphere, affecting air and water quality regulation. This shows that the ES type regulation is affected by the agroecosystem's capacity to offer supporting and provisioning services.

Agricultural management, therefore, directly affects soil functions. Among these, some of the most affected by the establishment and management of the agroecosystems in the study areas were: water infiltration, nutrient cycling, carbon sequestration and accumulation, sediment retention, and habitat (Table 2). The proposed managements provide various nutrients to the soil, mitigate the buildup of pathogens and pests that often occur in conventional systems, and improve soil structure and fertility, also affecting soil functioning.

"No fire use" and "agricultural consortium" were the criteria for the establishment and management of agroecosystems that showed higher potential for increasing ES provision.

Fire is one of the most important causes of impacts in the ecosystems (Zavala et al., 2014). Fire impacts on the soil are basically of two types: direct, as a result of the combustion of organic matter and of the temperatures reached in the soil; and indirect, as a result of changes in the other components of the ecosystem, such as reduction in vegetation cover, charred litter, or the deposition of partially burned plant residues and ash (Neary et al., 1999; Pausas \& Verdú, 2005, 2008; Zavala et al., 2014). Specifically in the Caatinga biome, the vulnerability to fires is worrying, since, in this case, agriculture is performed in a dry environment.

Agricultural consortium is an agricultural management present in silvopasture and agroforestry systems, which are recognized for presenting lower losses of nutrients and organic carbon. These systems are very well adapted to different regions of Brazil due to their characteristics concerning erosion control and nutrient cycling rates. Therefore, according to Aguiar et al. (2010), both systems are interesting alternatives to reduce the effect of pluvial soil erosion; however, these systems have annual rates of net contributions of dry matter that vary from 4.5 to $4.0 \mathrm{Mg} \mathrm{ha}^{-1}$ per year, respectively. Silvopasture systems, in special, have shown high efficiency in reducing soil pluvial erosion, recovering soil quality (Maia et al., 2006; Nogueira et al., 2008) and increasing carbon stocks (Maia et al., 2007). In terms of global impact, this system has also shown substantial potential to promote carbon 
Table 2. Relationship among the criteria for the establishment and management of the agroecosystems, in the study areas, and the environmental services (ES) types, soil functions, potential soil indicator, ES benefits, and policy relevance ${ }^{(1)}$.

\begin{tabular}{|c|c|c|c|c|c|c|}
\hline \multirow[t]{2}{*}{ Criteria } & \multicolumn{3}{|c|}{ ES type ${ }^{(2)}$} & \multirow{2}{*}{$\begin{array}{l}\text { Associated soil } \\
\text { functions }\end{array}$} & \multirow[t]{2}{*}{ Soil parameters or potential soil indicator } & \multirow[t]{2}{*}{ ES benefits } \\
\hline & Prov. & Sup. & Reg. & & & \\
\hline No fire use & +++ & +++ & +++ & $\begin{array}{c}\text { Water infiltration / } \\
\text { Habitat }\end{array}$ & $\begin{array}{l}\text { Soil porosity; bulk density; hydraulic conductivity; retention curve; } \\
\text { biomass carbon stock in soil and litter; microbial enzymatic activity } \\
\text { (carbon cycle); microbial enzymatic activity (phosphorus cycle); microbial } \\
\text { enzymatic activity (sulfur cycle); and soil macrofauna }\end{array}$ & $\begin{array}{l}\mathrm{Co}_{2} \text { mitigation; } \\
\text { stability in crop } \\
\text { production; air } \\
\text { purification; } \\
\text { biodiversity } \\
\text { protection; human } \\
\text { health }\end{array}$ \\
\hline
\end{tabular}

\begin{tabular}{|c|c|c|c|c|c|c|}
\hline $\begin{array}{l}\text { Rational use } \\
\text { of agroche- } \\
\text { micals }^{(3)}\end{array}$ & +++ & +++ & ++ & $\begin{array}{c}\text { Nutrient cycling / } \\
\text { Habitat }\end{array}$ & $\begin{array}{c}\text { Phosphorus }\left(\mathrm{P}_{2} \mathrm{O}_{5}\right) \text { content; potassium }\left(\mathrm{K}_{2} \mathrm{O}\right) \text { content; calcium }(\mathrm{CaO}) \\
\text { content; magnesium }(\mathrm{MgO}) \text { content; sum of bases }=\mathrm{Ca}+\mathrm{Mg}+\mathrm{K}+ \\
\mathrm{Na} \text {; biomass carbon stock in soil and litter; microbial enzymatic activity } \\
\text { (carbon cycle); microbial enzymatic activity (phosphorus cycle); microbial } \\
\text { enzymatic activity (sulfur cycle); and soil macrofauna }\end{array}$ & $\begin{array}{l}\text { Environment and } \\
\text { human health }\end{array}$ \\
\hline $\begin{array}{l}\text { No use of } \\
\text { agroche- } \\
\text { micals }^{(3)}\end{array}$ & +++ & +++ & ++ & Habitat & $\begin{array}{l}\text { Biomass carbon stock in soil and litter; microbial enzymatic activity } \\
\text { (carbon cycle); microbial enzymatic activity (phosphorus cycle); microbial } \\
\text { enzymatic activity (sulfur cycle); and soil macrofauna }\end{array}$ & $\begin{array}{l}\text { Environment and } \\
\text { human and health }\end{array}$ \\
\hline $\begin{array}{l}\text { Permanent } \\
\text { litter on soil } \\
\text { surface }\end{array}$ & +++ & +++ & +++ & $\begin{array}{l}\text { Water infiltration / } \\
\text { Nutrient cycling / } \\
\text { Sediment retention } \\
\quad \text { / Habitat }\end{array}$ & $\begin{array}{l}\text { Phosphorus }\left(\mathrm{P}_{2} \mathrm{O}_{5}\right) \text { content; potassium }\left(\mathrm{K}_{2} \mathrm{O}\right) \text { content; calcium }(\mathrm{CaO}) \\
\text { content; magnesium }(\mathrm{MgO}) \text { content; sum of bases }=\mathrm{Ca}+\mathrm{Mg}+\mathrm{K}+\mathrm{Na} \\
\text { soil porosity; bulk density; hydraulic conductivity; retention curve; and soil } \\
\text { macrofauna }\end{array}$ & $\begin{array}{l}\text { Water supply and } \\
\text { food production }\end{array}$ \\
\hline Crop rotation & +++ & +++ & ++ & $\begin{array}{l}\text { Water infiltration } \\
\text { / Nutrient } \\
\text { cycling / Carbon } \\
\text { sequestration and } \\
\text { accumulation / } \\
\text { Sediment retention } \\
\text { / Habitat }\end{array}$ & $\begin{array}{l}\text { Phosphorus }\left(\mathrm{P}_{2} \mathrm{O}_{5}\right) \text { content; potassium }\left(\mathrm{K}_{2} \mathrm{O}\right) \text { content; calcium }(\mathrm{CaO}) \\
\text { content; magnesium }(\mathrm{MgO}) \text { content; sum of bases }=\mathrm{Ca}+\mathrm{Mg}+\mathrm{K}+\mathrm{Na} \text {; } \\
\text { soil porosity; bulk density; hydraulic conductivity; retention curve; biomass } \\
\text { carbon stock in soil and litter; microbial enzymatic activity (carbon cycle); } \\
\text { microbial enzymatic activity (phosphorus cycle); microbial enzymatic } \\
\text { activity (sulfur cycle); and soil macrofauna }\end{array}$ & $\begin{array}{l}\text { Higher food } \\
\text { diversity; food } \\
\text { security; mitigation } \\
\text { of greenhouse } \\
\text { gases; biodiversity } \\
\text { protection }\end{array}$ \\
\hline $\begin{array}{l}\text { Agricultural } \\
\text { consortium }\end{array}$ & + & ++ & ++ & $\begin{array}{l}\text { Nutrient } \\
\text { cycling/ Carbon } \\
\text { sequestration and } \\
\text { accumulation/ } \\
\text { Sediment } \\
\text { retention/ Habitat }\end{array}$ & $\begin{array}{c}\text { Phosphorus }\left(\mathrm{P}_{2} \mathrm{O}_{5}\right) \text { content; potassium }\left(\mathrm{K}_{2} \mathrm{O}\right) \text { content; calcium }(\mathrm{CaO}) \\
\text { content; magnesium }(\mathrm{MgO}) \text { content; sum of bases }=\mathrm{Ca}+\mathrm{Mg}+\mathrm{K}+ \\
\text { Na; biomass carbon stock in soil and litter; microbial enzymatic activity } \\
\text { (carbon cycle); microbial enzymatic activity (phosphorus cycle); microbial } \\
\text { enzymatic activity (sulfur cycle); and soil macrofauna }\end{array}$ & $\begin{array}{l}\text { Higher food } \\
\text { diversity; food } \\
\text { security; mitigation } \\
\text { of greenhouse } \\
\text { gases; biodiversity } \\
\text { protection; } \\
\text { avoidance of land } \\
\text { use change }\end{array}$ \\
\hline Native trees & +++ & +++ & +++ & $\begin{array}{c}\text { Nutrient cycling } \\
\text { / Habitat / Water } \\
\text { infiltration }\end{array}$ & $\begin{array}{c}\text { Phosphorus }\left(\mathrm{P}_{2} \mathrm{O}_{5}\right) \text { content; potassium }\left(\mathrm{K}_{2} \mathrm{O}\right) \text { content; calcium }(\mathrm{CaO}) \\
\text { content; magnesium }(\mathrm{MgO}) \text { content; sum of bases }=\mathrm{Ca}+\mathrm{Mg}+\mathrm{K}+ \\
\text { Na; biomass carbon stock in soil and litter; microbial enzymatic activity } \\
\text { (carbon cycle); microbial enzymatic activity (phosphorus cycle); microbial } \\
\text { enzymatic activity (sulfur cycle); soil macrofauna; soil porosity; bulk } \\
\text { density; hydraulic conductivity; and retention curve }\end{array}$ & $\begin{array}{l}\text { Co2 mitigation; } \\
\text { air purification; } \\
\text { mitigation of } \\
\text { greenhouse gases; } \\
\text { biodiversity } \\
\text { protection }\end{array}$ \\
\hline
\end{tabular}

Phosphorus $\left(\mathrm{P}_{2} \mathrm{O}_{5}\right)$ content; potassium $\left(\mathrm{K}_{2} \mathrm{O}\right)$ content; calcium $(\mathrm{CaO})$ content; magnesium $(\mathrm{MgO})$ content; sum of bases $=\mathrm{Ca}+\mathrm{Mg}+\mathrm{K}+\mathrm{Na}$;

Inclusion $\begin{aligned} & \text { of animal } \\ & \text { component }\end{aligned} \quad+++\quad+++\quad++\quad$ Nutrient cycling soil porosity; bulk density; hydraulic conductivity; retention curve; biomass carbon stock in soil and litter; microbial enzymatic activity (carbon cycle); microbial enzymatic activity (phosphorus cycle); microbial enzymatic activity (sulfur cycle); and soil macrofauna

\footnotetext{
Strategy of

water use +++++ Water regulation /

in the rural $\quad++\quad+++\quad+++$ Sediment retention property

(1)Policy relevance: Plano setorial de mitigação e de adaptação às mudanças climáticas (Plano $\mathrm{ABC}$ ), the sector plan for mitigation and adaptation to climate change for low carbon in agriculture (Brasil, 2010); Programa produtor de água, the water producer program (ANA, 2016); Programa de aquisição de alimentos, the food acquisition program (Brasil, 2011); Programa nacional de alimentação escolar, the national school feeding program (FNDE, 2016). ${ }^{(2)}$ The qualitative estimates of the effects of each agricultural practice on ES types are represented by low (+) to high impacts (+++); Prov., provisioning; Sup., supporting; Reg., regulating. ${ }^{(3)}$ Chemical fertilizers and pesticides.
} 
sequestration (Assis et al., 2011), rising as an important land use practice to mitigate climate change impacts.

The set of indicators suggested to monitor changes in each agroecosystem, in order to show the effect of the proposed managements on soil functions, are presented in Table 2. The proposition of simple and easy indicators was prioritized, and all indicators are soil parameters validated by soil science that can be easily found in the literature. Biomass stock in soil and litter was the soil parameter considered the most appropriate to be used as an indicator in monitoring the impact of agroecosystems in ES provision. The reason for this is that soil organic carbon, a link to the carbon cycle, is mainly derived from biomass. This component can contain between 50 and $80 \%$ of natural forest carbon and more than $95 \%$ of the carbon in a grassland area (Ogle et al., 2005). Moreover, the carbon stock in the soil reflects the balance between the inputs of crop residues and other organic compounds and the outputs of decay, erosion, and leaching (Cowie et al., 2006). Therefore, the carbon turnover rate and mineralization of organic matter $(\mathrm{OM})$ lead to a higher carbon stock in temperate forests due to the lower activity of soil microbiota than in the tropics, where OM turnover is very fast (Bolin et al., 2000). The maintenance and improvement of soil quality are critical to its good productivity and fertility, which are related to the soil properties microbiology and chemistry (Banerjee et al., 2000). This shows the importance of the changes undergone by these properties during the year or due to land use systems in understanding soil quality indicators. This way, grazing, stocking rate, tillage, and other soil practices may affect the soil microbial activity and its role in the transformation of nutrients.

Four public policies in Brazil were associated with ES provisioning in the multiple agricultural system (MAS): "Plano setorial de mitigação e de adaptação às mudanças climáticas" (Plano $\mathrm{ABC}$ ), the sector plan for mitigation and adaptation to climate change for low carbon in agriculture; "Programa de aquisição de alimentos" (PAA), the food acquisition program; "Programa produtor de água" (PPA), the water producer program; and "Programa nacional de alimentação escolar" (PNAE), the national school feeding program. All these programs give farmers the opportunity to enhance their productivity, stimulating the shift from conventional production systems to the
MAS. However, it is worth highlighting that the MAS needs to reflect the community's reality and to be built in a participatory way, as recommend by Mattos et al. (2010).

\section{Conclusions}

1. Agroecosystems represent a way to practice multifunctional agriculture, as well as a source of environmental services (ES) provision.

2. An approach to assess soil functions in agroecosystems and their impacts on ES provision should consider as criteria the establishment and management of agroecosystems, taking into consideration the specificities of each area and a set of indicators to monitor changes.

3. The ES types most affected by the establishment and management of agroecosystems are the supporting and provisioning services, showing the potential of agricultural management in providing multiple services, besides food, fiber, and energy.

4. Water infiltration, nutrient cycling, carbon sequestration and accumulation, sediment retention, and habitat are the soil functions most affect by the establishment and management of the agroecosystems in the study areas.

5. "No fire use" and "agricultural consortium" are the criteria for the establishment and management of agroecosystems that show higher potential for increasing ES provision, whereas biomass stock in soil and litter is the most appropriate soil parameter to be used as an indicator to monitor the impact of agroecosystems in ES provision.

6. Four public policies in Brazil present opportunities for farmers to enhance their productivity, stimulating the shift from conventional production systems to agroecosystems.

\section{Acknowledgments}

To Empresa Brasileira de Pesquisa Agropecuária (Embrapa, project No. 02.12.01.03500.00), for financial support.

\section{References}

AGUIAR, M.I. de; MAIA, S.M.F.; XAVIER, F.A. da S.; MENDONÇA, E. de S.; ARAÚJO FILHO, J.A.; OLIVEIRA, T.S. de. Sediment, nutrient and water losses by water erosion under 
agroforestry systems in the semi-arid region in northeastern Brazil. Agroforestry Systems, v.79, p.277-289, 2010. DOI: 10.1007/s10457-010-9310-2.

ALTIERI, M.A. The ecological role of biodiversity in agroecosystems. Agriculture, Ecosystems and Environment, v.74, p.19-31. 1999. DOI: 10.1016/S0167-8809(99)00028-6.

ANA. Agência Nacional de Águas. Programa Produtor de Água. Available at: <http://produtordeagua.ana.gov.br>. Accessed on: July 282016.

ANDREWS, S.S.; CARROLL, C.R. Designing a soil quality assessment tool for sustainable agroecosystem management. Ecological Applications, v.11, p.1573-1585, 2001. DOI: 10.1890/1051-0761(2001)011[1573:DASQAT]2.0.CO;2.

ASSIS, C.P. de; XAVIER, F.A. da S.; MAIA, S.M.F.; NOGUEIRA, R.S.; ALENCAR, G.V. de; OLIVEIRA, T.S. de. Soil organic matter changes in agroforestry and organic farming in the semi-arid region of northeastern Brazil. Dynamic Soil, Dynamic Plant, v.5, p.36-44, 2011.

BAIDU-FORSON, J.J.; HODGKIN, T.; JONES, M. Introduction to special issue on agricultural biodiversity, ecosystems and environment linkages in Africa. Agriculture, Ecosystems and Environment, v.157, p.1-4, 2012. DOI: 10.1016/j. agee.2012.04.011.

BANERJEE, M.R.; BURTON, D.L.; MCCAUGHEY, W.P.P.; GRANT, C.A. Influence of pasture management on soil biological quality. Journal of Range Management, v.53, p.127-133, 2000. DOI: $10.2307 / 4003403$.

BARRAL, M.P.; BENAYAS, J.M.R.; MELI, P.; MACEIRA, N.O. Quantifying the impacts of ecological restoration on biodiversity and ecosystem services in agroecosystems: a global metaanalysis. Agriculture, Ecosystems and Environment, v.202, p.223-231, 2015. DOI: 10.1016/j.agee.2015.01.009.

BINDER, C.R.; HINKEL, J.; BOTS, P.W.G.; PAHL-WOSTL, C. Comparison of frameworks for analyzing social-ecological systems. Ecology and Society, v.18, p.26, 2013. DOI: 10.5751/ ES-05551-180426.

BOLIN, B.; SUKUMAR, R.; CIAIS, P. Global Perspectives. In: INTERGOVERNMENTAL PANEL ON CLIMATE CHANGES. Land use, land-use changes, and forestry: summary for policymakers: a special report of the Intergovernmental Panel Climate Changes. [S.1.]: Cambridge Press, 2000. p.23-51.

BÖRNER, J.; WUNDER, S.; WERTZ-KANOUNNIKOFF, S.; TITO, M.R.; PEREIRA, L.; NASCIMENTO, N. Direct conservation payments in the Brazilian Amazon: scope and equity implications. Ecological Economics, v.69, p.1272-1282, 2010. DOI: 10.1016/j.ecolecon.2009.11.003.

BRASIL. Decreto $\mathrm{n}^{\text {o }}$ 7.390, de 9 de dezembro de 2010. Regulamenta os arts. 6, 11 e 12 da Lei $n^{0} 12.187$, de 29 de dezembro de 2009, que institui a Política Nacional sobre Mudança do Clima - PNMC, e dá outras providências. Diário Oficial [da] República Federativa do Brasil, Brasília, 10 dez. 2010. Seção 1, p.4. Available at: <http://www.planalto.gov.br/ ccivil_03/_Ato2007-2010/2010/Decreto/D7390.htm>. Accessed on: July $2 \overline{8} 2016$.
BRASIL. Lei ${ }^{\circ} 12.512$, de 14 de outubro de 2011 . Institui o Programa de Apoio à Conservação Ambiental e o Programa de Fomento às Atividades Produtivas Rurais; altera as Leis $\mathrm{n}^{\mathrm{o}} \mathrm{s}$ 10.696, de 2 de julho de 2003, 10.836, de 9 de janeiro de 2004, e 11.326, de 24 de julho de 2006. Diário Oficial [da] República Federativa do Brasil, Brasília, 17 out. 2011. Seção 1, p.1. Available at: <http://www.planalto.gov.br/ccivil_03/_Ato20112014/2011/Lei/L12512.htm\#art33>. Accessed on: July 282016.

BRASIL. Ministério do Meio Ambiente. O bioma Cerrado. Available at: <http://www.mma.gov.br/biomas/cerrado>. Accessed on: July 28 2016a.

BRASIL. Secretaria Especial de Agricultura e do Desenvolvimento Agrário. Territórios da cidadania. Available at: $<$ http://www. mda.gov.br/portalmda/tags/territorios-da-cidadania $>$. Accessed on: July 282016 b.

COWIE, A.L.; SMITH, P.; JOHNSON, D. Does soil carbon loss in biomass production systems negate the greenhouse benefits of bioenergy? Mitigation and adaptation strategies for global changes, v.11, p.979-1002, 2006. DOI: 10.1007/s11027-0069030-0.

DALE, V.H.; POLASKY, S. Measures of the effects of agricultural practices on ecosystem services. Ecological Economics, v.64, p.286-296, 2007. DOI: 10.1016/j.ecolecon.2007.05.009.

DOMINATI, E.; PATTERSON, M.; MACKAY, A. A framework for classifying and quantifying the natural capital and ecosystem services of soils. Ecological Economics, v.69, p.1858-1868, 2010. DOI: 10.1016/j.ecolecon.2010.05.002.

DORAN, J.W.; PARKIN, T.B. Defining and assessing soil quality. In: DEFINING SOIL QUALITY FOR A SUSTAINABLE ENVIRONMENT, 1992, Minneapolis. Proceedings. Madison: Soil Science Society of America, 1994. p.3-21. (SSSA. Special publication, 35). Editors J.W. Doran, D.C Coleman, D.F. Bezdicek, and B.A. Stewart. DOI: 10.2136/sssaspecpub35.c1.

ELOY, L.; COUDEL, E.; TONI, F. Implementando pagamentos por serviços ambientais no Brasil: caminhos para uma reflexão críticas. Sustentabilidade em Debate, v.4, p.21-42, 2013.

FAO. FOOD AND AGRICULTURE ORGANIZATION OF THE UNITED NATIONS. Payments for ecosystem services and food security. 2011. Available at: <http://www.fao.org/docrep/014/ i2100e/i2100e.pdf $>$. Accessed on: July 282016.

FNDE. Fundo Nacional de Desenvolvimento da Educação. Legislação. Available at: <http://www.fnde.gov.br/programas/ alimentacao-escolar/alimentacao-escolar-legislacao $>$. Accessed on: July 282016.

FULTZ, L.M.; MOORE-KUCERA, J.; ZOBECK, T.M.; ACOSTA-MARTÍNEZ， V.; WESTER, D.B.; ALLEN, V.G. Organic carbon dynamics and soil stability in five semiarid agroecosystems. Agriculture, Ecosystems and Environment, v.181, p.231-240, 2013. DOI: 10.1016/j.agee.2013.10.004.

GLIESSMAN, S.R. Agroecology: the ecology of sustainable food systems. $2^{\text {nd }}$ ed. Boca Raton: CRC Press, 2006. 388p.

JALLOH, A.; ROY-MACAULEY, H.; SEREME, P. Major agroecosystems of West and Central Africa: brief description, species richness, management, environmental limitations and concerns. 
Agriculture, Ecosystems and Environment, v.157, p.5-16, 2012. DOI: $10.1016 /$ j.agee.2011.11.019.

LAL, R. Managing soils and ecosystems for mitigating anthropogenic carbon emissions and advancing global food security. BioScience, v.60, p.708-721, 2010. DOI: 10.1525/ bio.2010.60.9.8.

LESCOURRET, F.; MAGDA, D.; RICHARD, G.; ADAMBLONDON, A.-F.; BARDY, M.; BAUDRY, J.; DOUSSAN, I.; DUMONT, B.; LEFÈVRE, F.; LITRICO, I.; MARTINCLOUAIRE, R.; MONTUELLE, B.; PELLERIN, S.; PLANTEGENEST, M.; TANCOIGNE, E.; THOMAS, A.; GUYOMARD, H.; SOUSSANA, J.F-. A social-ecological approach to managing multiple agro-ecosystem services. Current Opinion in Environmental Sustainability, v.14, p.68-75, 2015. DOI: 10.1016/j.cosust.2015.04.001.

MAIA, S.M.F.; XAVIER, F.A. da S.; OLIVEIRA, T.S. de; MENDONÇA, E. de S.; ARAÚJO FILHO, J.A. de. Impactos de sistemas agroflorestais e convencional sobre a qualidade do solo no semi-árido cearense. Revista Árvore, v.30, p.837-848, 2006. DOI: 10.1590/S0100-67622006000500018.

MAIA, S.M.F.; XAVIER, F.A.S.; OLIVEIRA, T.S.; MENDONÇA, E.S.; ARAÚJO FILHO, J.A. Organic carbon pools in a Luvisol under agroforestry and conventional farming systems in the semiarid region of Ceará, Brazil. Agroforestry Systems, v.71, p.127138, 2007. DOI: 10.1007/s10457-007-9063-8.

MATTOS, L.; BRONDÍZIO, E.S.; ROMEIRO, A.; ORAIR, R. Agricultura de pequena escala e suas implicações na transição agroecológica da Amazônia brasileira. Amazônica, v.2, p.264-292, 2010. DOI: 10.18542/amazonica.v2i2.399.

MILLENNIUM ECOSYSTEM ASSESSMENT. Ecosystems and human well-being: synthesis. Washington: Island Press, 2005. $155 \mathrm{p}$.

NERY, D.G.; KLOPATEK, C.C.; DEBANO, L.F.; FFOLLIOTT, P.F. Fire effects on belowground sustainability: a review and synthesis. Forest Ecology and Management, v.122, p.51-71, 1999. DOI: $10.1016 /$ S0378-1127(99)00032-8.

NIEMEIJER, D.; GROOT, R.S. de. A conceptual framework for selecting environmental indicator sets. Ecological Indicators, v.8, p.14-25, 2008. DOI: 10.1016/j.ecolind.2006.11.012.

NOGUEIRA, R. da S.; OLIVEIRA, T.S. de; TEIXEIRA, A. dos S.; ARAÚJO FILHO, J.A. de. Redistribuição de carbono orgânico e fósforo pelo escoamento superficial em sistemas agrícolas convencionais e agroflorestais no semi-árido cearense. Revista Ceres, v.55, p.327-337, 2008.

OGLE, S.M.; BREIDT, F.J.; PAUSTIAN, K. Agricultural management impacts on soil organic carbon storage under moist and dry climatic conditions of temperate and tropical regions. Biogeochemistry, v.72, p.87-121, 2005. DOI: $10.1007 / \mathrm{s} 10533-$ 004-0360-2.

PAUSAS, J.G.; VERDÚ, M. Fire reduces morphospace occupation in plant communities. Ecology, v.89, p.2181-2186, 2008. DOI: 10.1890/07-1737.1.

PAUSAS, J.G.; VERDÚ, M. Plant persistence traits in fireprone ecosystems of the Mediterranean basin: a phylogenic approach. Oikos, v.109. p.196-202, 2005. DOI: 10.1111/j.00301299.2005.13596.x.

PORTER, J.; COSTANZA, R.; SANDHU, H.; SIGSGAARD, L.; WRATTEN, S. The value of producing food, energy, and ecosystem services within an agro-ecosystem. AMBIO, v.38, p.186-193, 2009. DOI: 10.1579/0044-7447-38.4.186.

POWER, A.G. Ecosystem services and agriculture: tradeoffs and synergies. Philosophical Transactions of the Royal Society B, v.365, p.2959-2971, 2010. DOI: 10.1098/rstb.2010.0143.

RENTING, H.; ROSSING, W.A.H.; GROOT, J.C.J.; VAN DER PLOEG, J.D.; LAURENT, C.; PERRAUD, D.; STOBBELAAR, D.J.; VAN ITTERSUM, M.K. Exploring multifunctional agriculture. A review of conceptual approaches and prospects for an integrative transitional framework. Journal of Environmental Management, v.90, p.S112-S123, 2009. Supplement 2. DOI: 10.1016/j.jenvman.2008.11.014.

RING, I. Integrating local ecological services into intergovernmental fiscal transfers: the case of the ecological ICMS in Brazil. Land Use Policy, v.25, p.485-497, 2008. DOI: 10.1016/j. landusepol.2007.11.001.

ROSSING, W.A.H.; ZANDER, P.; JOSIEN, E.; GROOT, J.C.J.; MEYER, B.C.; KNIERIM, A. Integrative modelling approaches for analysis of impact of multifunctional agriculture: a review for France, Germany and the Netherlands. Agriculture, Ecosystems and Environment, v.120, p.41-57, 2007. DOI: 10.1016/j. agee.2006.05.031.

SALOMÉ, C.; COLL, P.; LARDO, E.; METAY, A.; VILLENAVE, C.; MARSDEN, C.; BLANCHART, E.; HINSINGER, P.; LE CADRE, E. The soil quality concept as a framework to assess management practices in vulnerable agroecosystems: a case study in Mediterranean vineyards. Ecological Indicators, v.61, p.456465, 2016. DOI: 10.1016/j.ecolind.2015.09.047.

SCHIPANSKI, M.E.; BARBERCHECK, M.; DOUGLAS, M.R.; FINNEY, D.M.; HAIDER, K.; KAYE, J.P.; KEMANIAN, A.R.; MORTENSEN, D.A.; RYAN, M.R.; TOOKER, J.; WHITE, C. A framework for evaluating ecosystem services provided by cover crops in agroecosystems. Agricultural Systems, v.125, p.12-22, 2014. DOI: 10.1016/j.agsy.2013.11.004.

SEMINÁRIO DE GESTÃO PARTICIPATIVA EM SAÚDE DA REGIÃO SERRANA DO RIO DE JANEIRO, 1., 2005, [Rio de Janeiro]. [Síntese]. Brasília: Ed. do Ministério da Saúde, 2007. 68p. il. color. (Série D. Reuniões e Conferências; Série Cadernos Regionais).

SINGH, A.; SINGH, M.K.; GHOSHAL, N. Microbial biomass dynamics in a tropical agroecosystem: influence of herbicide and soil amendments. Pedosphere, v.26, p.257-264, 2016. DOI: 10.1016/S1002-0160(15)60040-6.

UNEP. United Nations Environment Programme. Towards multifunctional agriculture for social, environmental and economic sustainability. Available at: $<$ http://www.unep.org/dewa/ agassessment/docs/10505_Multi.pdf>. Accessed on: July 282016.

WANG, Q.; WANG, Y.; WANG, Q.; LIU, J. Impacts of 9 years of a new conservational agricultural management on soil organic carbon fractions. Soil and Tillage Research, v.143, p.1-6, 2014. DOI: $10.1016 /$ j.still.2014.05.004. 
WILLAARTS, B.; VOLK, M.; AGUILERA, P.A. Assessing the ecosystem services supplied by freshwater flows in Mediterranean agroecosystems. Agricultural Water Management, v.105, p.2131, 2012. DOI: 10.1016/j.agwat.2011.12.019.

YAHDJIAN, L.; SALA, O. e; HAVSTAD, K.M. Rangeland ecosystem services: shifting focus from supply to reconciling supply and demand. Frontier Ecology and Environment, v.13, p.44-51, 2015. DOI: 10.1890/140156.

ZAVALA, L.M.; CELIS, R. de; JORDÁN, A. How wildfires affect soil properties. A brief review. Cuadernos de Investigatión Geográfica, v.40, p.311-331, 2014. DOI: 10.18172/cig.2522.

Received on August 31, 2015 and accepted on March 7, 2016 